\title{
Effects of storage temperature and film treatment on sprouting and growth of ginseng seedlings
}

\author{
Eun Ha Chang*, Ji Hyun Lee, Ji Weon Choi, Sooyeon Lim, Il Sheob Shin \\ Postharvest Research Division, National Institute of Horticultural and Herbal Science, Wanju 55365, Korea
}

저장온도 및 필름처리가 묘삼의 생장과 품질에 미치는 영향

$$
\begin{gathered}
\text { 장은하* · 이지현 · 최지원 · 임수연 - 신일섭 } \\
\text { 국립원예특작과학원 저장유통과 }
\end{gathered}
$$

\begin{abstract}
This study investigated the effect of storage temperature $0,-2$, and $-4^{\circ} \mathrm{C}$ on growth and quality of ginseng seedlings for 10 months to cultivate ginseng sprouts. The effects of $50 \mu \mathrm{m}$ functional low density polyethylene (LDPE) containing $5 \%$ zeolite and pegmatite and $80 \mu \mathrm{m}$ nylon/polyethylene $(\mathrm{Ny} / \mathrm{PE})$ films on the storage of the ginseng seedlings were also investigated. The quality of the seedlings was visually inspected every two months and the growth of the sprouts investigated. After 4 months of storage, the growth and quality of the sprouts showed significant differences, which was the effect of the storage temperature. The growth of healthy ginseng sprouts were $58.3 \%$ at $0{ }^{\circ} \mathrm{C}, 72.1 \%$ at $-2{ }^{\circ} \mathrm{C}$, and $34.2 \%$ at $-4^{\circ} \mathrm{C}$. After storing the ginseng seedling for 8 months, a growth of $9.7 \%$ at $0{ }^{\circ} \mathrm{C}, 54.3 \%$ at $-2^{\circ} \mathrm{C}$, and $6.9 \%$ at $-4{ }^{\circ} \mathrm{C}$ was observed. The ginseng seedlings were packaged with functional and $\mathrm{Ny} / \mathrm{PE}$ films and the growth of the sprouts determined after 8 months of storage at $-2^{\circ} \mathrm{C}$. A growth rate of $56.7 \%$ was achieved using the functional film; however, no live ginseng seedlings were observed upon applying the $\mathrm{Ny} / \mathrm{PE}$ film.
\end{abstract}

Key words : ginseng, ginseng seedling, germination, postharvest, sprout

\section{서 론}

새싹인삼(Panax ginseng C. A. Meyer)의 재배는 먼저 미 숙배인 인삼 종자를 인위적으로 생장을 촉진시켜 씨눈 틔우 기(개갑)를 한 후 모밭에서 24개월 미만 재배한 모종삼(묘삼) 을 채굴해 새싹인삼 전용 수경 또는 상토에서 25 일-40일 정 도 재배를 한 후, 인삼의 뿌리와 어린잎 전체를 수확해 이용 하는 것으로 상대적으로 재배 기간이 짧은 특성을 가진다. 또, 인삼과 비교하여 새싹인삼은 계절에 제한을 받지 않아 연중 재배가 가능하고, 연작이 가능한 재배의 장점이 있고, 새싹인 삼 잎에도 진세노사이드 함량이 높은 것으로 보고되어 있다
(Jung, 2018; Park, 2017).

새싹인삼의 생산에 있어 묘삼의 품질은 매우 중요한데, 우 량 묘삼이란 형태적으로 뇌두(줄기와 잎이 함께 발달되어 있 는 기관)가 건실하고 몸체가 곧으며 뿌리의 길이는 $15 \mathrm{~cm}$ 이 상이고, $750 \mathrm{~g}$ 기준으로 800 본(개체) 정도이며, 개체당 0.95 $\mathrm{g}$ 이상인 것을 말한다. 우량 묘삼은 우수한 수삼이나 새싹인 삼의 생산을 위한 가장 기본적인 조건으로써 인삼이 자라는 동안 체형과 품질에 영향을 주기 때문에 우량 묘삼의 생산율 을 높이는 것은 중요하다.

지금까지 묘삼에 대한 연구로는 종자의 크기와 묘삼의 생 육과의 관계(Kim 등, 1981; Lee, 1984), 묘삼 생산 시 재배상

*Corresponding author. E-mail : cleo77@korea.kr, Phone : +82-63-238-6541, Fax : +82-63-238-6505

Received 24 February 2020; Revised 20 April 2020; Accepted 11 May 2020.

Copyright (c) The Korean Society of Food Preservation.

This is an Open Access article distributed under the terms of the Creative Commons Attribution Non-Commercial License (http://creativecommons.org/licenses/by-nc/4.0) which permits unrestricted non-commercial use, distribution, and reproduction in any medium, provided the original work is properly cited. 
토에 관한 연구(Jang 등, 2018; Park 등, 2014), 광도나 토양 수분함량 등 재배환경이 묘삼의 생육에 미치는 영향(Lee 등, 2008)에 관한 연구들이 보고되었고, 대부분 인삼종자의 생리 적 휴면타파나 봄파종을 위한 건조처리와 저장온도에 관한 연구(Suh 등, 2017; Suh 등, 2018; Suh 등, 2019), 저장기간 과 인삼종자 발아력과의 관계(Lee 등, 2004)가 다수 이루어 졌지만, 새싹인삼의 안정적인 생산을 위한 묘삼의 적정저장 온도나 저장방법에 관한 연구는 거의 보고된 것이 없다.

일반적으로 새싹인삼농가는 12 월에서 3 월 중 채굴된 묘삼 을 재배면적당 연중 6-7회 재배할 수 있는 양을 구입하여 골 판지 상자에 비닐을 깔고 묘삼을 적층한 후, 다시 비닐을 덮 어 골판지 상자를 $-3.5^{\circ} \mathrm{C}$ 정도의 저온저장고에 1 년 가까이 저 장하면서 새싹인삼을 재배하게 된다. 묘삼은 채굴 후 바로 재 배하거나 저온에서 단기간 저장 후 재배하여야 새싹인삼의 출아율이 높고 품질이 우수하다고 알려져 있고, 장기간 저온 저장 시에는 묘삼이 부패하거나, 묘삼의 활력이 떨어져 출아 율이 감소한다고 알려져 있지만, 이에 대한 묘삼의 연구 결과 는 많지 않다.

본 연구는 묘삼의 장기 저온저장 시 저장온도가 생장과 품 질에 미치는 영향을 조사하여 묘삼의 저장에 적합한 온도를 구명하고, 묘삼의 저장에 기능성 필름과 나일론 필름을 적용 했을 때 묘삼의 품질에 미치는 영향을 조사하여 묘삼 저장의 기초자료로 활용하고자 수행하였다.

\section{재료 및 방법}

\section{실험재료}

실험재료인 묘삼은 전라남도 장성에서 2019년 3월 채굴된 24개월 된 묘삼을 구입하여 채굴 후 즉시 실험실로 가져와 저장 실험에 사용하였다. 실험에 사용된 묘삼의 개체당 평균 무게는 $0.89 \pm 0.12 \mathrm{~g}$, 평균 직경은 $5.66 \pm 0.88 \mathrm{~mm}$, 평균 길이 는 $13.14 \pm 3.53 \mathrm{~cm}$ 이었다.

\section{묘삼 처리}

묘삼의 저장 온도별 출아율 조사를 위해 채굴된 묘삼에 묻 어있는 훍을 최대한 털어낸 후 각 온도 처리별 $100 \mathrm{~g}$ 씩 3 반복으로 나누어 low density polyethylene $50 \mu \mathrm{m}$ 필름에 포 장한 후 $1.5 \mathrm{~cm}$ 두께의 골판지 박스에 담아 $0^{\circ} \mathrm{C},-2^{\circ} \mathrm{C}$ 및 $-4^{\circ} \mathrm{C}$ 에 각각 10 개월 동안 저장하였다. 저장 2 개월마다 시료를 꺼 내어 $5^{\circ} \mathrm{C}$ 에서 5 일 동안 온도 순화를 시킨 후 1 차 육안조사를 하고, 건전한 묘삼만 전라남도 장성의 새싹인삼 수경재배 농 가에서 재식 전 수돗물로 세척하고, 세척 마지막 단계에 오존 수로 한 번 더 세척한 후 수경재배 베드에 재식하였으며, 재 배 20 일 경 출아율을 조사하였다.
묘삼의 저장에 기능성 필름 포장의 효과를 알아보기 위해 묘삼을 $100 \mathrm{~g}$ 씩 3반복으로 나누어 다공성 물질인 제올라이 트와 페그마타이트가 $5 \%$ 함유된 low density polyethylene $50 \mu \mathrm{m}$ (기능성 LDPE) 필름과 nylon/polyethylene $80 \mu \mathrm{m}$ $(\mathrm{Ny} / \mathrm{PE})$ 필름에 각각 포장한 후 $1.5 \mathrm{~cm}$ 두께의 골판지 박스 에 담아 $-2^{\circ} \mathrm{C}$ 에 10 개월 동안 저장하였다. 출아율 실험은 저장 8 개월부터 위와 동일하게 1 차 육안조사를 한 후 건전한 묘삼 만을 재식한 후 조사하였다.

묘삼의 출아율 조사를 위해 사용한 수경재배 방식은 고형 배지경을 변형한 방식으로 묘삼을 지탱해주는 지지체인 해면 체에 묘삼을 40-48뿌리 정도를 놓고 화분모양의 틀에 고정시 킨 후, 배수라인을 지지체마다 설치해 일정시간마다 배수가 되도록 설정하였으며, 해면체에 흡수된 수분을 묘삼의 뿌리 에 공급해 주는 방식으로 재배하였다. 새싹인삼의 재배에는 일반 수분만 공급되고, 인위적인 양액을 공급하지는 않았다.

새싹인삼 수경재배 비닐하우스의 환경은 하우스 내 온도 가 $23-25^{\circ} \mathrm{C}$, 습도 $65 \%$ 정도를 유지하도록 설정된 가온비닐 하우스였다. 비닐하우스는 천창이 개폐되는 2 중 비닐하우스 로 직사광선을 차단하기 위하여 차광율 $95 \%$ 의 검정색 차광 망을 외부의 산란비닐 위에 설치하여 광량을 조절하였으며, 하우스 측면 부분도 광량조절을 위해 지표면에서 높이 $2.2 \mathrm{~m}$ 까지 차광망을 설치하였다. 비닐하우스 내 새싹인삼의 재배 에 인공적인 광은 사용하지 않았으며, 자연광만을 사용하여 재배하였다.

\section{묘삼의 출아율 및 생장율 조사}

묘삼의 저장 온도에 따른 출아율 조사를 위해 $0^{\circ} \mathrm{C},-2^{\circ} \mathrm{C}$, $-4^{\circ} \mathrm{C}$ 에서 10 개월 동안 저장하면서 2 개월마다 꺼내어 저온저 장고 $5^{\circ} \mathrm{C}$ 에서 5 일간 순화시킨 후 1 차 조사에서는 육안조사로 건전한 묘삼과 부패 묘삼을 조사하였고, 건전한 묘삼만 새싹 인삼 수경재배 농가에 재식한 후 2차 생육조사로 묘삼의 출 아율을 조사하였다. 출아된 묘삼 즉, 새싹인삼은 다시 건전하 게 생장한 비율을 조사하였다. 1 차 육안조사에서는 묘삼의 곰팡이 발생, 뿌리 물러짐, 뿌리 동해, 뇌두 동해나 썩음 등을 조사하여 부패율로 나타내었다. 2 차 생육조사는 새싹인삼으 로 생장시킨 후 뿌리 곰팡이 발생, 뿌리 썩음, 잎의 이상증상 등이 발생하여 품질이 건전하지 못한 새싹인삼이 발생할 경 우, 묘삼의 출아비율에는 포함시켰지만 건전한 품질의 묘삼 비율에서는 제외시켰다. 1 차 육안조사의 비율은 각 온도별 저장된 묘삼의 개수에 대한 건전 또는 부패한 묘삼의 개수를 백분율로 나타내었고, 2 차 생육조사의 비율은 건전한 묘삼의 재식한 수에 대한 출아율 개수와 새싹인삼으로 건전하게 생 육한 개수를 각각 백분율로 나타내었다. 총 건전한 묘삼의 비 율은 저장 묘삼 개수 대비 건전하게 생육한 새싹인삼의 개수 
를 백분율로 나타내었고, 건전하게 생육하지 못한 새싹인삼 은 총 비건전한 묘삼의 비율로 나타내었다.

또한, 새싹인삼으로 생장 이후 저장온도에 따른 생육특성 의 차이를 조사하기 위해 지상부의 엽장, 엽폭, 줄기의 경장, 뿌리의 근장을 조사하였다.

\section{가용성 고형물 함량 측정}

저장 묘삼의 가용성 고형물 함량 변화는 크기가 균일한 묘 삼을 각 온도별, 또는 포장별로 6 개체씩 채취해 세절 후 1 $\mathrm{g}$ 씩 달고, 증류수 $5 \mathrm{~mL}$ 를 섞어 호모게나이저(T25, IKA Labortechnik, Germany)로 분쇄하여 $4^{\circ} \mathrm{C}$ 에서 $11,124 \times \mathrm{g}$ 으로 원심분리(Labogene 2236R, Gyrogen, Daejeon, Korea)하였 다. 원심분리 상등액을 디지털 굴절 당도계(PAL-1, Atago, Tokyo, Japan)로 측정하여 ${ }^{\circ}$ Brix로 나타내었다.

\section{유리당 분석}

유리당 함량은 가용성 고형물을 측정한 상등액 $1 \mathrm{~mL}$ 에 증류수로 다시 5 배 희석한 후 HPLC용 메탄올과 3 차 증류 수로 활성화한 Sep-pak $\mathrm{C}_{18}$ cartridge로 처리하고 $0.45 \mu \mathrm{m}$ membrane filter로 여과한 후 HPLC(1260 infinity II series, Agilent Technologies, Santa Clara, CA, USA)로 분석하였다. 분석조건으로 사용된 column은 sugar pak I $(6.5 \mathrm{~mm} \times 300$ $\mathrm{mm}$ Waters, Milford, MA, USA)을 사용하였고, oven의 온도 는 $70^{\circ} \mathrm{C}$, detector는 refractive index detector(1260 infinity II series, Agilent Technologies)를 사용하였고, 샘플 주입량은 $20 \mu \mathrm{L}$ 이었으며, 이동상은 $50 \mathrm{mg} / \mathrm{L} \mathrm{Ca-EDTA}$ 를 첨가한 3차 증류수를 $0.5 \mathrm{~mL} / \mathrm{min}$ 의 속도로 분석하였다. 유리당 함량은 농도별 sucrose, glucose 및 fructose(Sigma-Aldrich Inc., St. Louis, MO, USA) 표준곡선( $\left.\mathrm{R}^{2} \geq 0.998\right)$ 을 이용해 환산하여 나타내었다.

\section{통계처리}

본 실험에서 얻어진 결과의 통계처리는 각 항목에 대한 평 균 및 표준편차를 산출하여 SAS program(ver 9.2, SAS Institute Inc., Cary, NC, USA)을 이용하여 One-way ANOVA 를 실시하였다. 데이터의 처리 간 유의성 검정은 Duncan's multiple range test(DMRT)로 $\mathrm{p}<0.05$ 수준에서 검정하였다.

\section{결과 및 고찰}

\section{묘삼의 저장온도에 따른 출아율 및 생장율}

묘삼을 $0{ }^{\circ} \mathrm{C},-2{ }^{\circ} \mathrm{C},-4{ }^{\circ} \mathrm{C}$ 에 10 개월 저장하면서 저장온도에 따른 출아율을 조사하기 위해 2개월마다 꺼내어 온도 순화 후 1차 육안조사로 부패, 동할, 동해 등을 조사해 건전한 묘

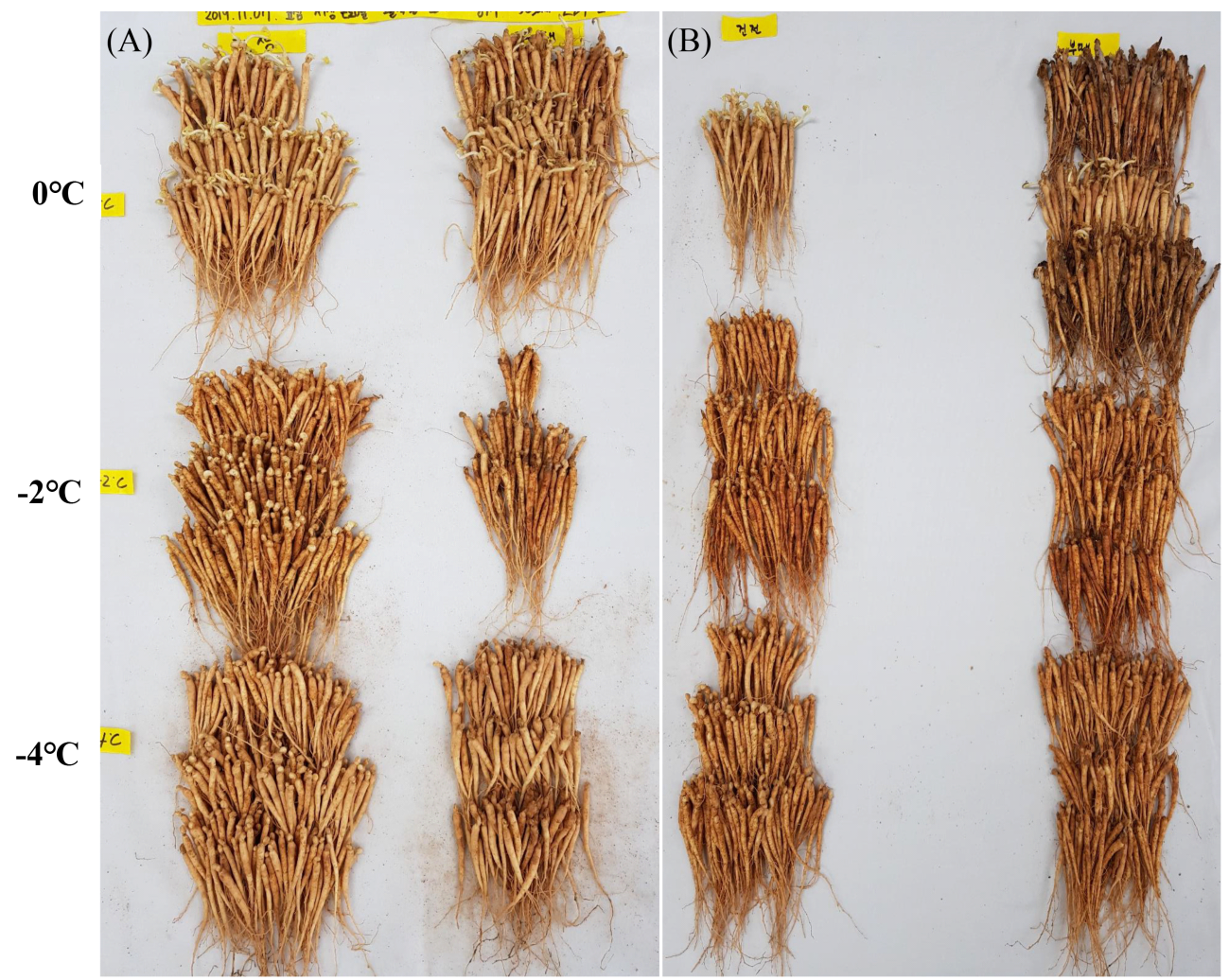

Fig. 1. Visible inspection of ginseng seedling according to storage temperature after storage of 8 (A) and 10 months (B). 
삼과 부패와 손실 묘삼으로 구분하였다(Fig. 1). 2차 조사는 건전한 묘삼을 직접 수경재배를 통해 새싹인삼으로 건전하게 생육되는지 조사하였다. 조사결과, 1 차 육안조사에서는 저장 4 개월까지 모든 저장온도에서 $90 \%$ 이상의 건전한 묘삼이 조 사되었고, 저장 6 개월 이후 저장온도별 묘삼의 품질이 달라져 $0^{\circ} \mathrm{C}$ 는 $63.2 \%,-2^{\circ} \mathrm{C}$ 는 $85.8 \%,-4^{\circ} \mathrm{C}$ 는 $86.8 \%$ 가 건전한 묘삼으 로 조사되었다. 그리고 저장 8 개월 이후는 $-2^{\circ} \mathrm{C}$ 에서 건전 묘 삼이 $79.7 \%$ 였으나, $0^{\circ} \mathrm{C}$ 와 $-4{ }^{\circ} \mathrm{C}$ 에서는 각각 $42.9 \%, 48.1 \%$ 로 낮은 건전율을 보였다(Table 1). 육안조사결과, $0^{\circ} \mathrm{C}$ 저장의 경우 저장 2 개월부터 일부 묘삼에서 출아가 진행되었고, 저장 4 개월에는 $90 \%$ 이상 출아가 되었다. 저장 6 개월에 $0^{\circ} \mathrm{C}$ 의 건 전묘삼의 비율이 $63.2 \%$ 인 것도 저장 중 출아된 새싹이 동해 로 고사되었기 때문인 것으로 조사되었다. $-4^{\circ} \mathrm{C}$ 는 육안으로 6개월까지는 건전한 묘삼의 비율이 $86.8 \%$ 로 조사되었지만, 저장 8 개월에 $48.1 \%$ 로 감소한 이유가 뇌두의 눈이 동해로 고 사되었기 때문이며, 묘삼 뿌리의 동해나 동할도 $-4^{\circ} \mathrm{C}$ 에서 나 타나 묘삼의 손실율에 영향을 미친 것으로 조사되었다.

묘삼을 육안조사 후 건전한 묘삼만을 수경재배하여 2차 조 사로 출아율과 새싹인삼으로 건전하게 생장한 비율(Fig. 2)을
조사하였다(Table 1). 그 결과, 저장 2 개월까지 출아율은 $0^{\circ} \mathrm{C}$, $-2{ }^{\circ} \mathrm{C},-4^{\circ} \mathrm{C}$ 에서 각각 $98.7 \%, 88.7 \%, 89.0 \%$ 로 조사되었지만, 저장 4 개월에는 각각 $74.8 \%, 80.7 \%, 44.8 \%$ 로, 저장 6 개월에 는 $86.6 \%, 77.4 \%, 37.7 \%$ 로, 저장 8 개월에는 $38.5 \%, 69.4 \%$, $41.7 \%$ 로 저장온도별 출아율에 큰 차이를 보였다. 새싹인삼 으로 건전하게 성장한 비율은 출아율보다 현저히 감소하는 것으로 나타나 저장 4 개월에 $0^{\circ} \mathrm{C},-2^{\circ} \mathrm{C},-4^{\circ} \mathrm{C}$ 에서 각각 $60.9 \%$, $74.1 \%, 35.4 \%$ 로, 저장 6 개월에는 각각 $62.2 \%, 70.6 \%, 11.8 \%$ 로, 저장 8 개월에는 $21.6 \%, 60.5 \%, 9.0 \%$ 로 조사되었다.

묘삼을 1차 육안검사와 2차 출아율 및 생장조사(Table 1) 를 통해 총 건전한 묘삼의 비율을 조사한 결과, $0^{\circ} \mathrm{C}$ 는 저장 4 개월까지 $50 \%$ 의 건전한 묘삼의 비율을 나타내었고, $-2^{\circ} \mathrm{C}$ 는 저장 8 개월까지 $50 \%$ 의 건전한 묘삼의 비율을 나타내었으며, $-4^{\circ} \mathrm{C}$ 는 저장 2 개월까지 $50 \%$ 이상의 건전한 묘삼의 비율을 나타내었다.

본 결과를 통해 묘삼을 장기간 저장하면서 새싹인삼을 재 배할 경우, $-2^{\circ} \mathrm{C}$ 에 저장하는 것이 저장 중 묘삼의 출아를 억 제하고, 뇌두의 동해를 피하면서 안정적으로 저장할 수 있다 는 것을 밝혔다.

Table 1. The effect of storage temperature on the growth and quality of ginseng seedlings during cultivation

(unit: \%)

\begin{tabular}{|c|c|c|c|c|c|c|c|c|}
\hline & \multirow{2}{*}{ Inspection method } & \multirow{2}{*}{$\begin{array}{c}\text { Temperature } \\
\left({ }^{\circ} \mathrm{C}\right)\end{array}$} & \multicolumn{6}{|c|}{ Storage period (month) } \\
\hline & & & 0 & 2 & 4 & 6 & 8 & 10 \\
\hline \multirow{3}{*}{$\begin{array}{l}1 \text { st visible } \\
\text { inspection }\end{array}$} & \multirow{3}{*}{$\begin{array}{l}\text { Visible good ginseng } \\
\text { seedling ratio after } \\
\text { temperature cycling }\end{array}$} & 0 & 100 & $93.9 \pm 5.8^{1) \mathrm{a} 2)}$ & $91.1 \pm 8.9^{\mathrm{a}}$ & $63.2 \pm 16.2^{\mathrm{b}}$ & $42.9 \pm 5.8^{\mathrm{b}}$ & $11.7 \pm 20.2^{\mathrm{b}}$ \\
\hline & & -2 & 100 & $96.5 \pm 3.5^{\mathrm{a}}$ & $95.2 \pm 2.2^{\mathrm{a}}$ & $85.8 \pm 8.7^{\mathrm{ab}}$ & $79.7 \pm 10.4^{\mathrm{a}}$ & $48.5 \pm 15.9^{b}$ \\
\hline & & -4 & 100 & $97.8 \pm 2.2^{\mathrm{a}}$ & $94.9 \pm 3.2^{\mathrm{a}}$ & $86.8 \pm 5.8^{\mathrm{a}}$ & $48.1 \pm 21.1^{\mathrm{ab}}$ & $53.6 \pm 17.5^{\mathrm{a}}$ \\
\hline \multirow{6}{*}{$\begin{array}{l}\text { 2nd growth } \\
\text { inspection }\end{array}$} & \multirow{3}{*}{$\begin{array}{l}\text { Sprouting ratio of healthy } \\
\text { ginseng seedling after } 1 \text { st } \\
\text { visible inspection }\end{array}$} & 0 & 100 & $98.7 \pm 1.2^{\mathrm{a}}$ & $74.8 \pm 11.6^{\mathrm{a}}$ & $86.6 \pm 8.1^{\mathrm{a}}$ & $38.5 \pm 17.4^{\mathrm{b}}$ & $28.6 \pm 49.5^{\mathrm{ab}}$ \\
\hline & & -2 & 100 & $88.7 \pm 1.0^{\mathrm{b}}$ & $80.7 \pm 7.0^{\mathrm{a}}$ & $77.4 \pm 7.6^{\mathrm{a}}$ & $69.4 \pm 5.9^{\mathrm{a}}$ & $67.2 \pm 11.1^{\mathrm{a}}$ \\
\hline & & -4 & 100 & $89.0 \pm 4.5^{\mathrm{b}}$ & $44.8 \pm 15.2^{\mathrm{b}}$ & $37.7 \pm 15.9^{\mathrm{b}}$ & $41.7 \pm 11.6^{\mathrm{b}}$ & $37.3 \pm 16.5^{\mathrm{b}}$ \\
\hline & \multirow{3}{*}{$\begin{array}{l}\text { Good quality ratio of } \\
\text { ginseng sprouts }\end{array}$} & 0 & 100 & $98.7 \pm 1.2^{\mathrm{a}}$ & $60.9 \pm 14.0^{\mathrm{ab}}$ & $62.2 \pm 3.9^{\mathrm{b}}$ & $21.6 \pm 6.3^{\mathrm{a}}$ & $11.4 \pm 19.8^{\mathrm{a}}$ \\
\hline & & -2 & 100 & $88.7 \pm 1.0^{\mathrm{b}}$ & $74.1 \pm 8.0^{\mathrm{a}}$ & $70.6 \pm 3.7^{\mathrm{a}}$ & $60.5 \pm 3.6^{\mathrm{b}}$ & $54.2 \pm 12.4^{\mathrm{b}}$ \\
\hline & & -4 & 100 & $89.0 \pm 4.5^{\mathrm{b}}$ & $35.4 \pm 14.7^{\mathrm{b}}$ & $11.8 \pm 0.8^{\mathrm{c}}$ & $9.0 \pm 8.8^{\mathrm{a}}$ & $12.7 \pm 8.7^{\mathrm{a}}$ \\
\hline \multirow{6}{*}{$\begin{array}{c}\text { Total } \\
\text { inspection }\end{array}$} & \multirow{3}{*}{$\begin{array}{l}\text { Total good sprouting rate } \\
\text { after 1st and } \\
\text { 2nd inspection }\end{array}$} & 0 & 100 & $92.8 \pm 2.9^{\mathrm{a}}$ & $58.3 \pm 16.0^{\mathrm{ab}}$ & $41.3 \pm 5.1^{\mathrm{b}}$ & $9.7 \pm 4.7^{b}$ & $4.0 \pm 6.9^{\mathrm{b}}$ \\
\hline & & -2 & 100 & $86.3 \pm 1.1^{\mathrm{a}}$ & $72.1 \pm 8.6^{\mathrm{a}}$ & $58.4 \pm 4.3^{\mathrm{a}}$ & $54.3 \pm 7.8^{\mathrm{a}}$ & $28.2 \pm 6.4^{\mathrm{a}}$ \\
\hline & & -4 & 100 & $87.7 \pm 4.6^{\mathrm{a}}$ & $37.2 \pm 12.6^{\mathrm{b}}$ & $15.1 \pm 1.8^{\mathrm{c}}$ & $6.9 \pm 5.7^{b}$ & $10.6 \pm 1.7^{\mathrm{b}}$ \\
\hline & \multirow{3}{*}{$\begin{array}{l}\text { Total quality loss rate after } \\
1 \text { st and 2nd inspection }\end{array}$} & 0 & 0 & $7.2 \pm 2.9^{\mathrm{a}}$ & $41.7 \pm 16.0^{\mathrm{ab}}$ & $58.7 \pm 5.1^{\mathrm{b}}$ & $90.3 \pm 4.7^{\mathrm{a}}$ & $96.0 \pm 6.9^{\mathrm{a}}$ \\
\hline & & -2 & 0 & $13.7 \pm 1.1^{\mathrm{a}}$ & $27.9 \pm 8.6^{\mathrm{b}}$ & $41.6 \pm 4.3^{\mathrm{c}}$ & $45.7 \pm 7.8^{\mathrm{b}}$ & $71.8 \pm 6.4^{\mathrm{b}}$ \\
\hline & & -4 & 0 & $12.3 \pm 4.6^{\mathrm{a}}$ & $62.8 \pm 12.6^{\mathrm{a}}$ & $84.9 \pm 1.8^{\mathrm{a}}$ & $93.1 \pm 5.7^{\mathrm{a}}$ & $89.4 \pm 1.7^{\mathrm{a}}$ \\
\hline
\end{tabular}

${ }^{1)}$ Values are mean \pm SD $(n=3)$.

${ }^{2)}$ Means with different letters indicate a significant different within each film treatment by Duncan's multiple range test $(\mathrm{p}<0.05)$. ${ }^{\mathrm{a}-\mathrm{c}}$ significant different among treatments. 


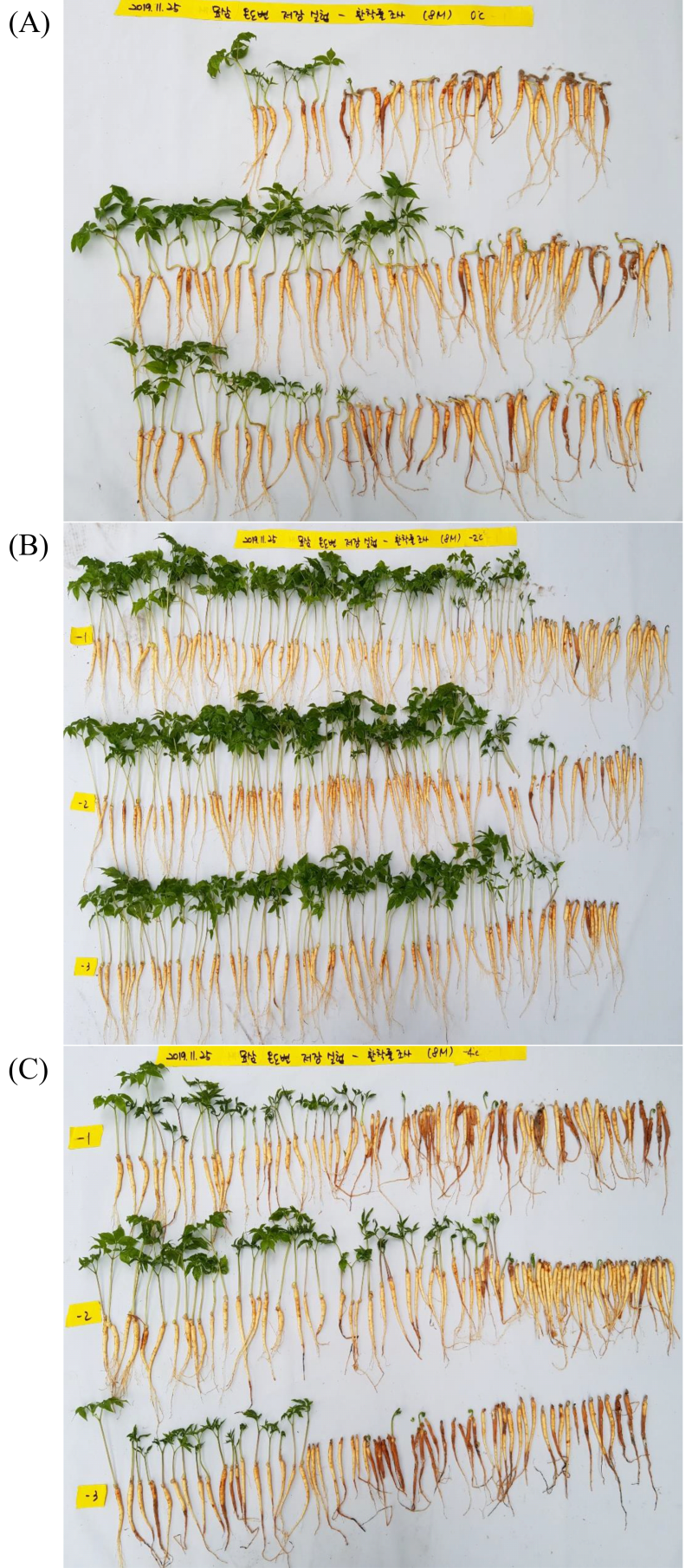

Fig. 2. Growth and quality of ginseng seedlings stored at (A) $0^{\circ} \mathrm{C}$, (B) $-2^{\circ} \mathrm{C}$, and $(\mathrm{C})-4^{\circ} \mathrm{C}$ after 8 months.

묘삼을 재식 후 새싹인삼의 생육특성을 조사하기 위해 저 장 8 개월과 10 개월에 새싹인삼의 엽장, 엽폭, 경장, 근장을 측정하였다(Fig. 3). 저장 8개월 된 묘삼으로 재배한 새싹인 삼의 생육특성을 조사한 결과, $-2^{\circ} \mathrm{C}$ 에 저장된 묘삼의 새싹인 삼에서 엽폭, 경장의 길이가 $0^{\circ} \mathrm{C}$ 나 $-4^{\circ} \mathrm{C}$ 에 저장된 묘삼의 새
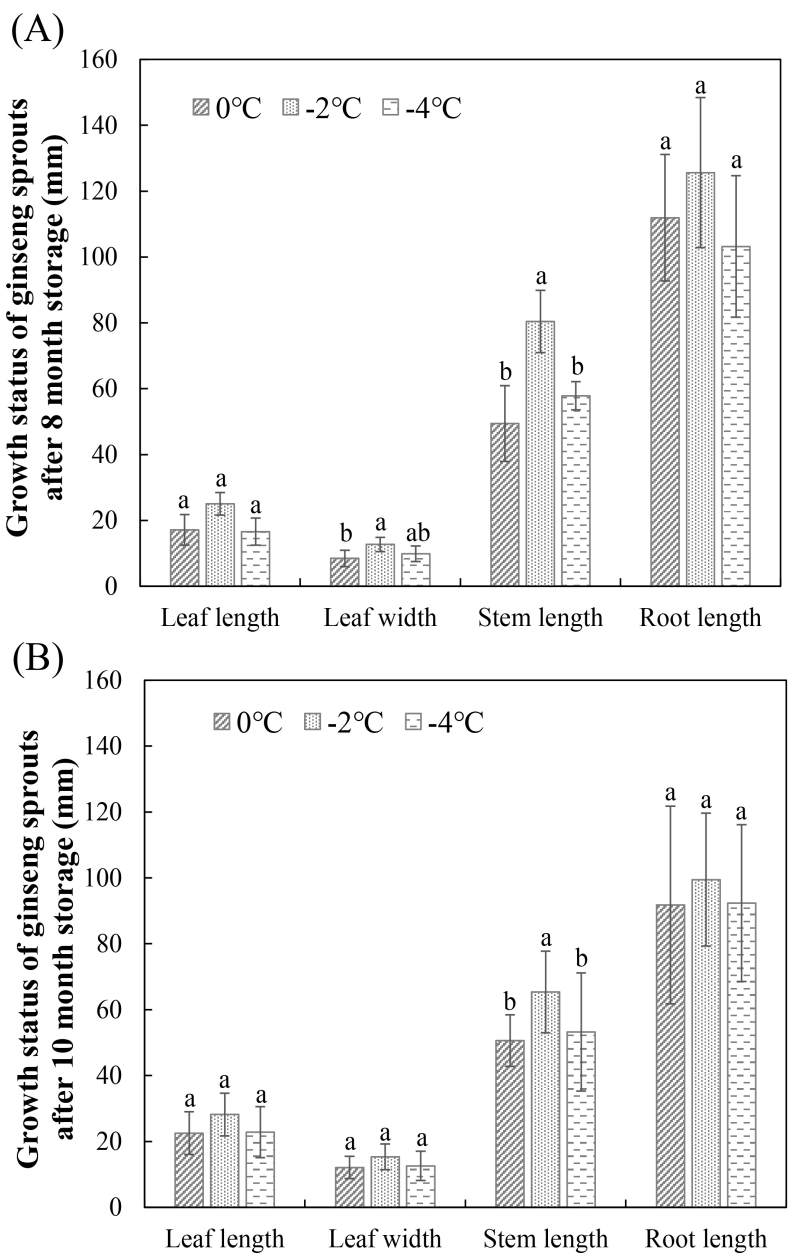

Fig. 3. Growth status of ginseng sprouts stored at $0^{\circ} \mathrm{C},-2^{\circ} \mathrm{C}$, and $-4^{\circ} \mathrm{C}$ storage temperature after storage of (A) 8 and (B) 10 months.

Values are mean \pm SD ( $n=30$ ). Means with different letters on the bars indicate a significant different within each film treatment by Duncan's multiple range test $(p<0.05)$. ${ }^{a, b}$ significant different between treatment.

싹인삼보다 유의적으로 긴 것으로 조사되었다. 엽장과 근장 은 저장온도별 유의적인 차이는 나지 않았지만, 평균값으로 $-2^{\circ} \mathrm{C}$ 의 새싹인삼의 길이가 길고 품질이 좋은 것으로 조사되 었다(Fig. 3A).

저장 10 개월 된 묘삼(Fig. 3B)으로 재배한 새싹인삼의 생 육특성도 저장 8 개월과 유사하게 $-2^{\circ} \mathrm{C}$ 에 저장된 묘삼의 새싹 인삼에서 엽폭, 엽장, 경장, 근장의 길이가 긴 것으로 조사되 었다. 그러나 저장 10 개월 된 묘삼의 새싹인삼이 저장 8 개월 된 묘삼의 새싹인삼보다 생육이 저조한 것으로 조사되었다. 수경재배 비닐하우스의 환경은 하우스 내 온도가 $23-25^{\circ} \mathrm{C}$, 습도 $65 \%$ 가 유지되도록 설정하고, 자연광은 차광막을 이용 해 조절한 가온비닐하우스로 계절마다 비닐하우스 내 환경이 새싹인삼의 생육에 미치는 영향을 최소화시킨 상태에서 재배 하였다. 따라서 저장 8 개월과 10 개월 사이의 새싹인삼의 생 
육의 차이는 저장기간 중 묘삼의 생리적 활성이 변화하기 때 문인 것으로 보여진다. 본 실험에서 저장 8개월 이전 새싹인 삼의 생육 데이터는 제시하지 않았지만, 저장기간이 짧을수록 새싹인삼의 품질은 더 우수한 것으로 조사되었으며, $-2^{\circ} \mathrm{C}$ 저 장이 묘삼의 생리적 특성을 잘 유지시켜 주는 온도로 조사되 었다.

지금까지 묘삼의 저장방법이나 저장온도에 대한 연구는 거의 없으며, 인삼 종자의 저장온도에 따른 출아율 조사가 대 부분이다. 인삼 종자의 출아율 조사에서 종자가 형태학적 · 생리학적 휴면을 벗어나 출아가 되기 위한 온도 및 기간에 대한 연구결과, 형태적 휴면 타파는 $15-20^{\circ} \mathrm{C}$ 에서 약 3 개월, 생리적 휴면타파는 $4-5^{\circ} \mathrm{C}$ 에서 약 60 일에서 100 일 정도 소요 된다(Kwon 등, 2001; Lee 등, 1986)고 하였다. 그러나 농가 에서 개갑(씨눈 틔우기)이 끝난 종자를 노지에 묻거나 $4-5^{\circ} \mathrm{C}$ 에서 겨울동안 보관하면 봄 파종하기 전에 출아하거나 부패 하는 문제가 발생할 수 있어 $-2-0^{\circ} \mathrm{C}$ 에 보관하는 것을 권장하 고 있다(RDA, 2013). Suh 등(2017; 2018; 2019)의 인삼 종자 적정 저장온도 구명 결과에서는 종자가 3 개월 이상 $2^{\circ} \mathrm{C}$ 에 저 장된 경우 봄파종 전 $50 \%$ 이상 발아하였지만, $-2^{\circ} \mathrm{C}$ 저장에서 는 파종 전 발아되는 종자가 없었으며, 파종 후에도 출아율이 $70 \%$ 라 보고하였고, $-3.5^{\circ} \mathrm{C}$ 에 저장 시 봄파종 후 출아가 매우 저조하였다고 보고하였다. 인삼 종자의 발아에 있어 영하의 온도에 저장할 경우 동결 피해와 휴면타파의 지연 문제가 생 길 수 있으며, 인삼 종자의 동결 한계 온도는 종자의 수분함량 에 따라 -3.5- $-9.6^{\circ} \mathrm{C}$ 에 분포한다고 하였다(Lee와 Proctor, 1996). 동결에 따른 손상은 세포 내 수분이 얼었을 때 보다 해빙이 될 때 발생하게 되며, 특히 동결과 해빙이 지속적으로 반복될 때 더 크게 발생하게 된다(Lee와 Proctor, 1996)고 보고 하였다.

종자에서 출아되어 인삼의 형태를 가진 묘삼이 $-4^{\circ} \mathrm{C}$ 에서 저장 4 개월에 외관은 정상이지만, 건전한 총출아 비율이 $37.2 \%$ 로 저조한 것도 동결 한계온도에서 장기간 저장되면서 동결피해를 받은 것으로 추측된다.

\section{묘삼의 저장온도에 따른 가용성 고형물 및 유리당 함량}

묘삼을 $0^{\circ} \mathrm{C},-2^{\circ} \mathrm{C},-4^{\circ} \mathrm{C}$ 에 10 개월 동안 저장하면서 저장온 도에 따른 가용성 고형물 함량과 유리당 함량 변화를 조사하 기 위해 2달마다 묘삼을 분석하였다. 조사결과, Fig. 4에서와 같이 저장기간이 길어질수록 모든 온도구간에서 가용성 고형 물 함량이 증가하는 것으로 조사되었고, $-4^{\circ} \mathrm{C}$ 에 저장된 묘삼 의 가용성 고형물 함량이 $0^{\circ} \mathrm{C}$ 나 $-2^{\circ} \mathrm{C}$ 에 저장된 묘삼보다 함량 이 높게 조사되었다. 묘삼은 1 년생 인삼으로 인삼의 내부성 분의 $50 \%$ 이상을 구성하는 물질이 전분으로 조사되었는데 (Chang 등, in press), 전분이 저장 중 단당류로 전환되면서

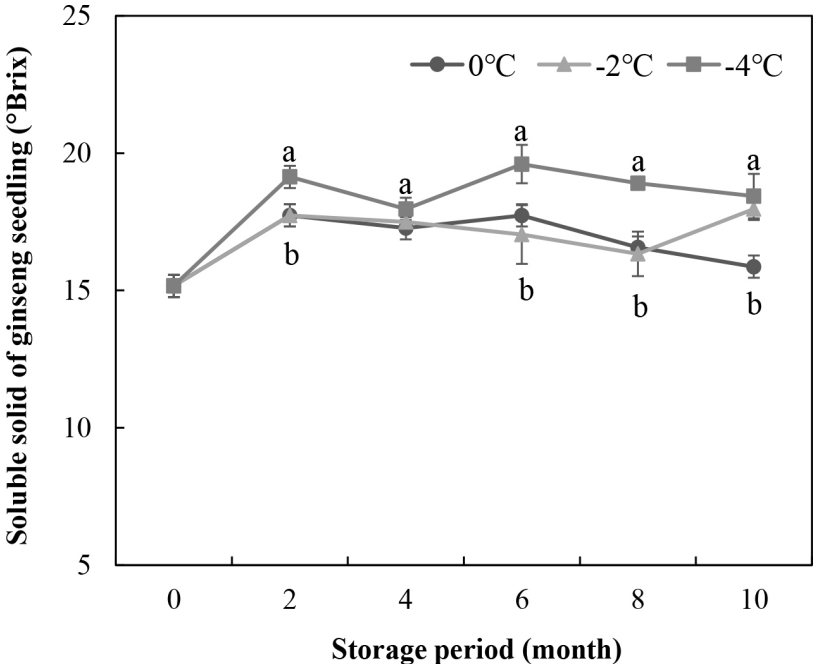

Fig. 4. Soluble solid content of ginseng seedling during storage at various temperatures.

Values are mean \pm SD $(n=5)$. Means with different letters indicate a significant different within each film treatment by Duncan's multiple range test $(p<0.05)$. ${ }^{a, b}$ significant different among treatments.

가용성 고형물 함량이 증가된 것으로 조사되었다.

가용성 고형물 함량 증가에 영향을 미치는 유리당 함량을 조사한 결과(Fig. 5) 묘삼에 존재하는 유리당은 sucrose, glucose, fructose였고, sucrose가 대표적인 유리당으로 조사 되었다. 초기 sucrose 함량은 $3.4 \mathrm{mg} / \mathrm{g}$, glucose 함량은 0.6 $\mathrm{mg} / \mathrm{g}$, fructose 함량은 $0.7 \mathrm{mg} / \mathrm{g}$ 에서 저장기간이 늘어날수록 sucrose 함량은 모든 저장온도에서 증가하는 경향을 보였고, 저장온도가 낮을수록 sucrose 함량이 증가하여 $0{ }^{\circ} \mathrm{C}$ 나 $-2^{\circ} \mathrm{C}$ 보 다 $-4^{\circ} \mathrm{C}$ 에 저장된 묘삼에서 sucrose가 빠르게 증가하였다. 그 러나 sucrose 함량은 저장 4 개월이나 6개월 이후에는 다시 감 소하여 저장 10 개월에 $0^{\circ} \mathrm{C}$ 에 저장된 묘삼은 초기보다 더 낮 은 sucrose 함량을 나타내었다. Glucose 함량과 fructose 함량 또한 저장 2 개월이나 4 개월까지 함량이 증가하다가 이후 급 격히 감소하는 경향을 보였다. $0^{\circ} \mathrm{C}$ 와 $-4^{\circ} \mathrm{C}$ 에 저장된 묘삼의 경우 저장 2 개월까지 함량이 증가한 후 8 개월까지 증가한 양 과 비슷한 함량을 유지하다가 저장 10 개월에 감소하였지만, $-2^{\circ} \mathrm{C}$ 에 저장된 묘삼의 경우 저장 2 개월까지 약간 증가한 후 이후 급격히 감소하는 경향을 보였다. 특히 fructose보다 glucose 함량의 감소가 더 빠른 것으로 조사되었다.

일반적으로 가용성 sucrose의 증가는 저온에 취약한 세포 막을 보호하고, 저온내성을 유도하기 위해 세포의 삼투 전위 를 효과적으로 제어하는 것으로 알려져 있다(Ackerson, 1981; Welling과 Palva, 2006). 또한 활성산소종에 반응하여 세포막의 안정화 및 호르몬 대사에 관여한다(Bohnert와 Sheveleva, 1998; Zeng 등, 2011). Lin Q 등(2019)은 granulebound starch synthase 1 , beta-amylase, sucrose synthase 2 , 
(A)

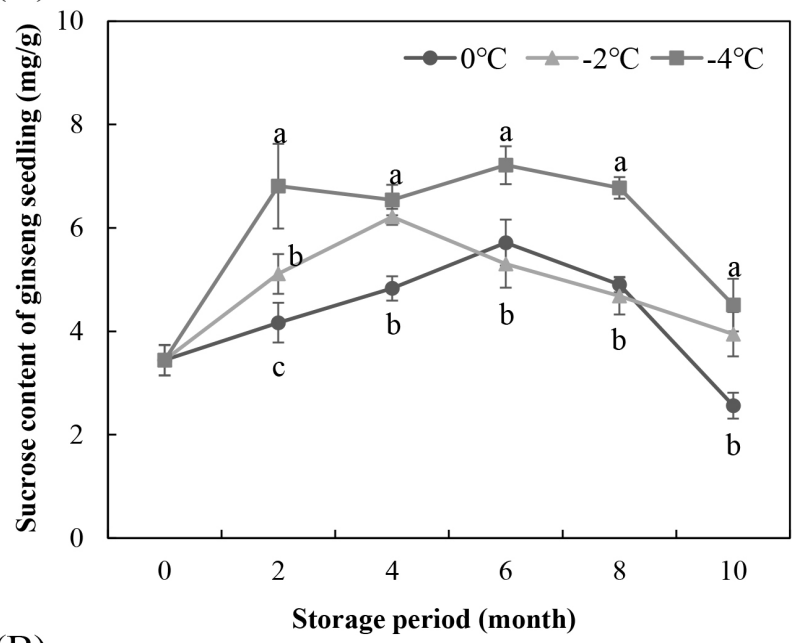

(B)

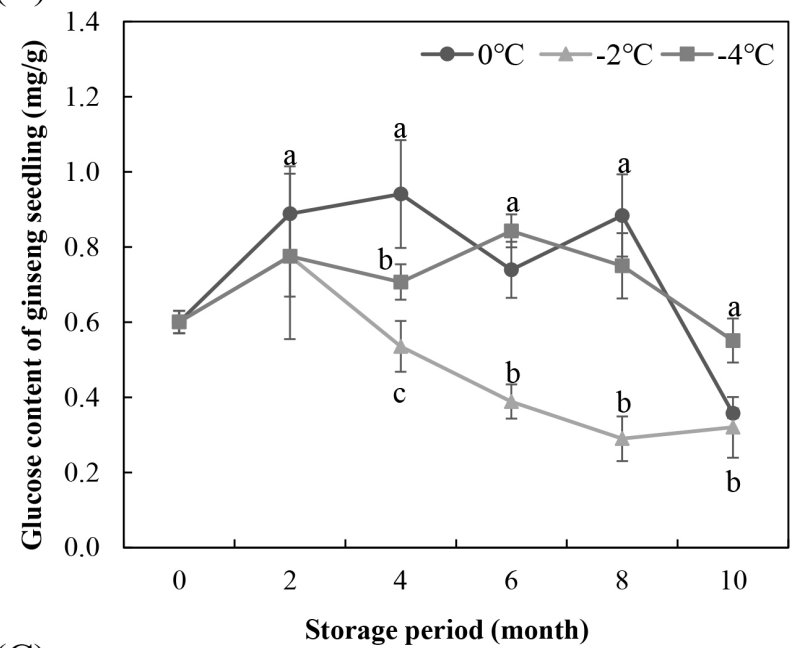

(C)

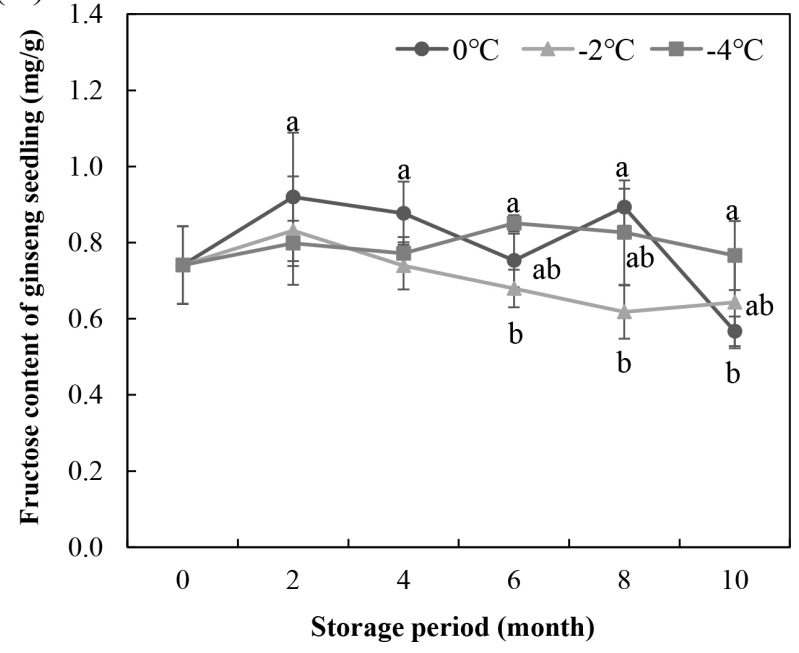

Fig. 5. Sucrose (A), glucose (B), and fructose (C) contents of ginseng seedling during storage at different temperatures.

Values are mean \pm SD $(n=5)$. Means with different letters indicate a significant different within each film treatment by Duncan's multiple range test $(\mathrm{p}<0.05) .{ }^{\mathrm{a}-\mathrm{c}}$ significant different among treatments. invertase inhibitor 및 fructokinase와 같은 효소가 감자를 저 온에 저장하는 동안 감자 전분을 가용성 당으로 전환시키는 데 결정적인 역할을 수행한다고 보고하였다. 그들의 결과에 서 granule-bound starch synthase 1은 하향 조절되는 반면, beta-amylase는 상향 조절되었는데, 이는 전분분해가 저온에 의해 촉진되었음을 나타낸다. 또한, invertase inhibitor는 저 온 하에서 상당히 하향 조절되었는데, 이는 저온 스트레스에 반응하여 감자의 당 축적을 조절하는데 invertase inhibitor의 중요성을 시사한다고 보고하였다.

\section{묘삼의 필름처리에 따른 출아율 및 생장율}

묘삼의 저장 시 사용되는 필름의 종류가 묘삼의 출아율이 나 생육에 미치는 영향을 조사하기 위해 기능성 필름과 $\mathrm{Ny} / \mathrm{PE}$ 필름에 각각 $100 \mathrm{~g}$ 씩 포장한 후 골판지 상자에 담아 $-2^{\circ} \mathrm{C}$ 에 저장하면서 8 개월과 10 개월에 시료를 꺼내어 $5^{\circ} \mathrm{C}$ 에서 5 일 동안 온도 순화를 시킨 후 출아율과 생장율을 조사하였 다. 조사결과, Table 2와 Fig. 6 와 같이 Ny/PE 필름에 8개월 저장된 묘삼의 경우 1 차 육안검사 시 뇌두부위가 검게 변하 여 묘삼이 대부분 고사된 것으로 조사되었다. 필름 개봉 전 필름 내부의 $\mathrm{O}_{2}$ 및 $\mathrm{CO}_{2}$ 가스농도를 측정한 결과, $\mathrm{O}_{2}$ 농도는 $1.91 \%, \mathrm{CO}_{2}$ 농도는 $38.9 \%$ 로 측정되었고, 필름 개봉 시 알코 올 냄새가 나는 것으로 보아 $\mathrm{Ny} / \mathrm{PE}$ 필름으로 포장된 묘삼이 저장기간 동안 호흡을 하면서 필름 내 산소를 완전히 소모하 고 혐기적인 환경으로 되어 대사활동이 불가능하였으리라 판 단된다. 또한, $\mathrm{Ny} / \mathrm{PE}$ 필름으로 포장 시 필름 내부에 수분이 고여 묘삼의 부패나 품질 저하를 촉진시킬 수 있을 것으로 보였다. 묘삼을 $-2^{\circ} \mathrm{C}$ 의 저온에 저장하여 생리활성을 최대한 억제시키더라도 대사활동이 완전 정지된 것은 아니기 때문에 $\mathrm{Ny} / \mathrm{PE}$ 필름과 같이 내 · 외부로 공기의 유동이 전혀 이루어 지지 않는 완전 밀폐된 필름을 이용하여 저장할 경우 오히려 대사활동에 장해를 주어 묘삼의 저장에는 적합하지 않는 필 름처리구로 조사되었다.

반면, 기능성 필름으로 포장한 묘삼은 저장 8개월에 수경재 배 후 $74.3 \%$ 의 출아율을 보였고, 건전한 새싹인삼의 비율은 $67.2 \%$ 로 조사되었다. 수경재배 전 - 후 묘삼의 개체수 대비 건전 출아율의 비율은 $56.7 \%$ 를 나타내어 $\mathrm{Ny} / \mathrm{PE}$ 필름으로 포장한 묘삼의 결과와 큰 차이를 보였다. 기능성 필름의 개봉 전 필름 내부의 $\mathrm{O}_{2}$ 및 $\mathrm{CO}_{2}$ 가스농도를 측정한 결과 $\mathrm{O}_{2}$ 농도 는 $12.9 \%, \mathrm{CO}_{2}$ 농도는 $4.6 \%$ 로 측정되었고, 필름 내부 수분 의 축적도 발생하지 않았다.

따라서 묘삼의 저온저장 시 필름을 적용할 경우, 공기의 유 동이 원활이 이루어져 내부 $\mathrm{O}_{2}$ 농도를 일정 수준 이상 유지 해주는 필름을 사용하는 것이 묘삼의 출아와 생육에 좋은 것 으로 조사되었다. 
Table 2. The effect of film treatment of the growth and quality of ginseng seedlings for cultivation

(unit: \%)

\begin{tabular}{|c|c|c|c|c|c|}
\hline & \multirow{2}{*}{ Inspection method } & \multirow{2}{*}{$\begin{array}{l}\text { Temperature } \\
\left({ }^{\circ} \mathrm{C}\right)\end{array}$} & \multicolumn{3}{|c|}{ Storage period (month) } \\
\hline & & & 0 & 8 & 10 \\
\hline \multirow{2}{*}{$\begin{array}{l}\text { 1st visual } \\
\text { inspection }\end{array}$} & \multirow{2}{*}{$\begin{array}{l}\text { Visible good ginseng seedling ratio } \\
\text { after temperature cycling }\end{array}$} & $\mathrm{Ny} / \mathrm{PE}$ film & 100 & $9.0 \pm 11.4^{1) \mathrm{b} 2)}$ & $0.0 \pm 0.0^{\mathrm{b}}$ \\
\hline & & Functional film & 100 & $82.2 \pm 7.3^{\mathrm{a}}$ & $41.0 \pm 8.1^{\mathrm{a}}$ \\
\hline \multirow{4}{*}{$\begin{array}{l}\text { 2nd growth } \\
\text { inspection }\end{array}$} & \multirow{2}{*}{$\begin{array}{l}\text { Sprouting ratio of healthy ginseng } \\
\text { seedling after } 1 \text { st visible inspection }\end{array}$} & $\mathrm{Ny} / \mathrm{PE}$ film & 100 & $4.8 \pm 8.2^{b}$ & $0.0 \pm 0.0^{\mathrm{b}}$ \\
\hline & & Functional film & 100 & $74.3 \pm 6.4^{\mathrm{a}}$ & $78.3 \pm 14.2^{\mathrm{a}}$ \\
\hline & \multirow{2}{*}{ Good quality ratio of ginseng sprouts } & Ny/PE film & 100 & $0.0 \pm 0.0^{\mathrm{b}}$ & $0.0 \pm 0.0^{\mathrm{b}}$ \\
\hline & & Functional film & 100 & $67.2 \pm 4.4^{\mathrm{a}}$ & $68.7 \pm 12.9^{\mathrm{a}}$ \\
\hline \multirow{4}{*}{ Total inspection } & \multirow{2}{*}{$\begin{array}{l}\text { Total good sprouting rate after } 1 \text { st } \\
\text { and 2nd inspection }\end{array}$} & Ny/PE film & 100 & $0.0 \pm 0.0^{\mathrm{b}}$ & $0.0 \pm 0.0^{\mathrm{b}}$ \\
\hline & & Functional film & 100 & $56.7 \pm 8.8^{\mathrm{a}}$ & $27.8 \pm 4.6^{\mathrm{a}}$ \\
\hline & \multirow{2}{*}{$\begin{array}{l}\text { Total quality loss rate after } 1 \text { st and } \\
\text { 2nd inspection }\end{array}$} & $\mathrm{Ny} / \mathrm{PE}$ film & 0 & $100 \pm 0.0^{\mathrm{a}}$ & $100 \pm 0.0^{\mathrm{a}}$ \\
\hline & & Functional film & 0 & $43.3 \pm 8.8^{\mathrm{b}}$ & $72.2 \pm 4.6^{\mathrm{b}}$ \\
\hline
\end{tabular}

${ }^{1)}$ Values are mean $\pm \mathrm{SD}(\mathrm{n}=3)$.

${ }^{2}$ Means with different letters indicate a significant different within each film treatment by Duncan's multiple range test $(\mathrm{p}<0.05)$. ${ }^{\mathrm{a}, \mathrm{b}}$ significant different among treatment.

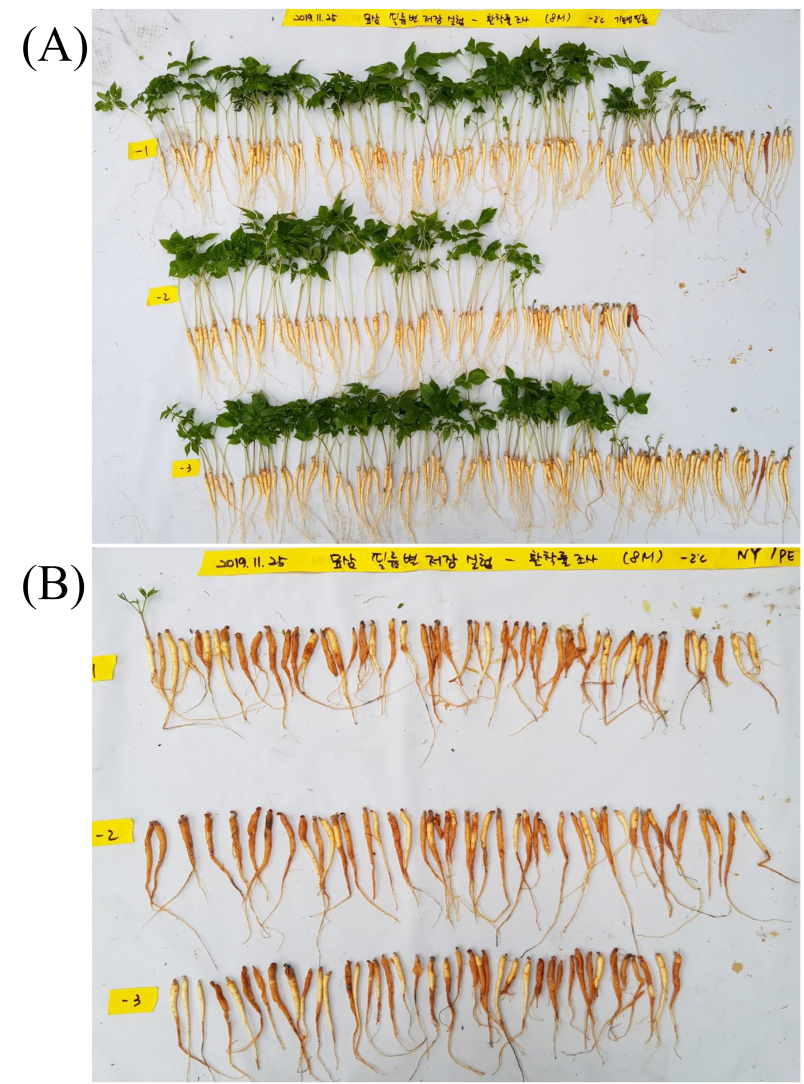

Fig. 6. Growth and quality of ginseng sprouts depending on the treatment of LDPE (A) and Ny/PE (B) films after 8 months storage.
결론적으로 묘삼의 저온 장기저장에 적합한 온도와 필름 적용 실험을 통해 $-2^{\circ} \mathrm{C}$ 에서 가스투과가 있는 필름을 사용하 는 것이 건전한 새싹인삼의 생육을 위해 적합한 것으로 조사 되었다.

\section{요 약}

본 연구는 새싹인삼 재배용으로 이용하기 위한 묘삼의 장 기 저온저장 시 저장온도가 생장과 품질에 미치는 영향을 조 사하여 묘삼의 저장에 적합한 온도를 구명하고, 묘삼의 저장 에 기능성 필름과 $\mathrm{Ny} / \mathrm{PE}$ 필름을 적용했을 때 묘삼의 품질에 미치는 영향을 조사하였다. 묘삼을 $0^{\circ} \mathrm{C},-2^{\circ} \mathrm{C},-4^{\circ} \mathrm{C}$ 에 10 개월 동안 저장하면서 저장 2 개월마다 1 차 육안조사로 묘삼의 품 질과 2 차 생육조사로 묘삼을 새싹인삼으로 재배 후 생장 상 태와 품질을 조사한 결과, 저장 4 개월 이후 새싹인삼의 생장 과 품질이 묘삼의 저장온도에 따라 유의적인 차이를 보였다. 즉, 저장 4 개월 된 묘삼의 건전한 새싹인삼으로의 생장은 $0^{\circ} \mathrm{C}$ 에서 $58.3 \%,-2^{\circ} \mathrm{C}$ 에서 $72.1 \%,-4^{\circ} \mathrm{C}$ 에서 $37.2 \%$ 로 조사되었고, 저장 8 개월 된 묘삼은 $0^{\circ} \mathrm{C}$ 에서 $9.7 \%,-2^{\circ} \mathrm{C}$ 에서 $54.3 \%,-4^{\circ} \mathrm{C}$ 에서 $6.9 \%$ 의 생장율을 나타내었다. 또한, 묘삼의 저장에 가 스투과도가 높은 기능성 필름과 가스투과도가 없는 $\mathrm{Ny} / \mathrm{PE}$ 필름으로 포장한 후 $-2^{\circ} \mathrm{C}$ 에 저장했을 때 저장 8 개월에 가스 투과도가 높은 기능성 필름으로 포장한 묘삼의 새싹인삼으로 의 생장은 $56.7 \%$ 로 조사되었지만, $\mathrm{Ny} / \mathrm{PE}$ 필름으로 포장한 
묘삼의 새싹인삼으로의 생장은 $0 \%$ 로 조사되어, 가스투과가 없는 필름으로 포장할 경우 묘삼이 고사되는 것으로 조사되 었다. 실험을 통해 묘삼의 저온 장기저장에 적합은 온도와 저 장 방법은 $-2^{\circ} \mathrm{C}$ 에서 가스투과가 있는 필름을 사용하는 것이 적합한 것으로 조사되었다.

\section{감사의 글}

본 논문은 농촌진흥청 연구사업(과제번호: PJ01515302)에 의해 이루어진 결과로 이에 감사드립니다.

\section{Conflict of interests}

The authors declare no potential conflict of interest.

\section{ORCID}

Eun Ha Chang https://orcid.org/0000-0002-5647-8842

\section{References}

Ackerson RC. Osmoregulation in cotton in response to water stress II. Leaf carbohydrate status in relation to osmotic adjustment. Plant Physiol, 67, 489-493 (1981)

Bohnert HJ, Sheveleva E. Plant stress adaptations-making metabolism move. Curr Opin Plant Biol, 1, 267-274 (1998)

Chang EH, Lee JH, Do KR, Choi JW, Hong YP, Shin IS. Internal quality factors affecting the occurrence of inner white areas and inner cavities in red ginseng. Hortic Environ Biotechnol, (in press)

Jang MH, Kim SH, Choi YA, Won DY, Kim IS. Characterizing the effects of microclimate on the growth of ginseng seedlings using multi-layer bed production facilities. Korean J Medicinal Crop Sci, 26, 490-497 (2018)

Jung HB. Processing and quality characteristics of the high value-added seafood products using Panax ginseng sprout. Ph D Thesis, Gyeongsang National University, Korea, p 8 (2018)

Kim JM, Lee SS, Kim YT. Effect of seed size on seedling performance in Panax ginseng. Korean J Ginseng Sci, 5, 85-91 (1981)

Kwon WS, Lee JH, Lee MG. Optimum chilling terms for germination of the dehisced ginseng (Panax ginseng C. A. Meyer) seed. J Ginseng Res, 25, 167-170 (2001)

Lee JC, Byen JS, Proctor JTA. Dormancy of ginseng seed as influenced by temperature and gibberellic acid. Korean J Crop Sci, 31, 220-225 (1986)

Lee JC, Proctor JTA. Low temperature tolerance of Panax quinquefolium. Korean J Ginseng Sci, 20, 179-183 (1996)

Lee JH, Lee SS, Ahn IO, Kang JY, Lee MG. Relationship between storage periods and germination ability of dehisced seeds of Panax ginseng C. A. Meyer. J Ginseng Res, 28, 215-218 (2004)

Lee SS, Cheon SR, Kim YT, Lee CH. Effect of seedling characters on the growth of ginseng plant on field: 3 . Relationship between seedling weight and the growth of ginseng plant on field. Korean J Ginseng Sci, 8, 57-64 (1984)

Lee SW, Kim CG, Hyun DY, Yeon BY, Lee KW, Cha SW. Effect of light transmission ratio and soil moisture content on growth characteristics of seedling in Panax ginseng C. A. Meyer. Korean J Medicinal Crop Sci, 16, 207-210 (2008)

Lin Q, Xie Y, Guan W, Duan Y, Wang Z, Sun C. Combined transcriptomic and proteomic analysis of cold stress induced sugar accumulation and heat shock proteins expression during postharvest potato tuber storage. Food Chem, 297, 124991 (2019)

Park HW, Jang IB, Kim YC, Mo HS, Park KC, Yu J, Kim JU, Lee EH, Kim KH, Hyun DY. Growth characteristics of ginseng seedlings as affected by mixed nursery soil under polyethylene film covered greenhouse. Korean $\mathrm{J}$ Medicinal Crop Sci, 22, 363-368 (2014)

Park MY. A study on the optimization of wild-simulated ginseng in the forest. MS Thesis, Silla University, Korea, p 1-11 (2017)

Rural Development Administration (RDA). Guide for Seedling Cultural of Ginseng. Rural Development Administration, Jeonju, Korea, p 10-13 (2013)

Suh SJ, Jang IB, Jang IB, Moon JW, Yu J. Optimum storage temperature for spring sowing of Panax ginseng seeds. Korean J Medicinal Crop Sci, 27, 390-396 (2019)

Suh SJ, Jang IB, Yu J, Jang IB, Park HW, Seo TC, Kweon $\mathrm{KB}$. Effect of seed dehydration and temperature during cold-stratification on the seed quality of Panax ginseng C. A. Meyer. Korean J Medicinal Crop Sci, 25, 209-216 
(2017)

Suh SJ, Yu J, Jang IB, Moon JW, Lee SW, Jang IB. Effect of storage temperature and seed treatment on emergence and growth properties of Panax ginseng at spring-sowing. Korean J Medicinal Crop Sci, 26, 401-407 (2018)

Welling A, Palva ET. Molecular control of cold acclimation in trees. Physiol Plant, 127, 167-181 (2006)

Zeng Y, Yu J, Cang J, Liu L, Mu Y, Wang J, Zhang D. Detection of sugar accumulation and expression levels of correlative key enzymes in winter wheat (Triticum aestivum) at low temperatures. Biosci Biotechnol Biochem, 75, 681-687 (2011) 